\title{
Kable elektryczne w kontekście zagrożenia pożarowego i przepisów ochrony przeciwpożarowej
}

\author{
Электрические кабели в контексте угрозы возгорания \\ и правил противопожарной защиты
}

Electric Cables in the Context of Fire Hazard and Fire Protection Regulations

\begin{abstract}
ABSTRAKT
Cel: Głównym celem niniejszego artykułu jest przegląd wymagań w zakresie bezpieczeństwa pożarowego kabli elektrycznych i światłowodów. Dodatkowym celem jest przedstawienie sposobów badania ich cech palności.

Wprowadzenie: Od 2016 roku kable elektryczne i światłowodowe są uznawane za wyroby budowlane. W związku z tym przy wprowadzaniu ich na rynek podlegają one - jak każdy inny wyrób budowlany - przepisom rozporządzenia CPR. W artykule przedstawione zostały wymagania stawiane kablom przed dopuszczeniem ich do obrotu na rynku europejskim (w tym także polskim) oraz właściwości tych wyrobów weryfikowane w obszarze bezpieczeństwa pożarowego. W związku z tym, że norma zharmonizowana nie obejmuje swoim zakresem pewnych grup kabli (głównie w systemach bezpieczeństwa pożarowego), w kontekście tych grup omówiono wymagania krajowe stosowane przy wprowadzaniu ich na rynek. W artykule dokonano również syntetycznej analizy przepisów krajowych w obszarze wymagań dla kabli elektrycznych i światłowodowych w kontekście ochrony przeciwpożarowej. Metodologia: Dokonano przeglądu wymagań prawnych na gruncie europejskim oraz krajowym w kontekście możliwości wprowadzenia do obrotu kabli elektrycznych lub światłowodowych. Przeprowadzono również analizę stanu prawnego w Polsce pod kątem wymagań z zakresu ochrony przeciwpożarowej dla kabli elektrycznych lub światłowodowych stosowanych w budownictwie, a także zaprezentowano metodyki badawcze stosowane do charakteryzowania tych wyrobów i oceny związanego z nimi zagrożenia pożarowego.

Wnioski: Podczas doboru okablowania w budynku, oprócz aspektów użytkowych w postaci funkcji elektrycznych, należy zwrócić również uwagę na zagrożenie pożarowe, jakie stanowi duże nagromadzenie kabli w wiązkach kablowych. Zaprezentowany w artykule przegląd potwierdził, że nie wszystkie kwestie są uregulowane przepisami prawa, a w niektórych przypadkach są uregulowane niewłaściwie. W związku z powyższym projektanci i rzeczoznawcy ds. zabezpieczeń przeciwpożarowych powinni stosować własną wiedzę techniczną na temat kabli, tym bardziej, że przepisy określają dla tych wyrobów tylko minimalne wymagania. Pomimo funkcjonowania od ponad roku (dwóch przy założeniu okresu przejściowego) wymagań CPR w zakresie określenia reakcji na ogień kabli elektrycznych, przepisy dotyczące zastosowania poszczególnych klas nie zostały opracowane, przez co nie ma jasnego przekazu, jakie wymagania należy stawiać kablom elektrycznym. Oprócz znajomości obowiązujących wymagań dla kabli elektrycznych i światłowodów, sposobu ich badań oraz zagrożeń, jakie niesie za sobą okablowanie w budynku, przy doborze okablowania potrzebna jest także wiedza techniczna. Należałoby przyjąć, aby przynajmniej w obszarze dróg ewakuacji, stosowane były kable elektryczne i światłowody o wyższych klasach reakcji na ogień. Słowa kluczowe: kable elektryczne, światłowody, reakcja na ogień, CPR, znak B, badanie kabli, palność kabli, wymagania dla kabli Typ artykułu: artykuł przeglądowy
\end{abstract}

Przyjęty: 18.09.2018; Zrecenzowany: 17.12.2018; Zatwierdzony: 21.12.2018;

Identyfikatory ORCID autorów: W. Klapsa - 0000-0002-6481-587X; D. Małozięć - 0000-0003-4929-8656; A. Wolańska - 0000-0002-4609-8459;

Procentowy wkład merytoryczny: W. Klapsa - 50\%; D. Małozięć - 30\%; A. Wolańska - 20\%;

Proszę cytować: BiTP Vol. 52 Issue 4, 2018, pp. 184-201, https://dx.doi.org/10.12845/bitp.52.4.2018.11;

Artykuł udostępniany na licencji CC BY-SA 4.0 (https://creativecommons.org/licenses/by-sa/4.0/).

\section{ABSTRACT}

Purpose: The purpose of this article is to review the fire safety requirements for electric and optical fibre cables and to present the methods for testing their flammability characteristics.

Introduction: Since 2016, electric and optical fibre cables have been recognised as construction products. Therefore, like all other construction products, they are subject to the Construction Products Regulation (CPR). This paper presents the requirements which must be met before placing cables on the European (including Polish) market, and their properties verified in the field of fire safety. Due to the fact that the harmonised standard does not cover 
certain groups of cables (mainly in fire safety systems), the national requirements for placing the product on the market are also discussed. This paper also includes a synthetic analysis of national regulations in the area of requirements for electrical and optical fibre cables in the context of fire protection. Methodology: A review of European and national legal requirements was performed in the context of the possibility of placing electric or optical fibre cables on the market as construction products. An analysis of the legal status in Poland was also carried out in terms of fire protection requirements for electric or optical fibre cables normally used in construction. This paper also presents the research methodologies allowing the characterisation and assessment of the fire hazard.

Conclusions: The large accumulation of cables in cable bundles is also a major fire hazard. The review confirmed that not all issues regarding the fire hazard caused by cables are regulated by law, and at some points they even lack proper regulation. However, this does not exempt designers and fire safety experts from using the available technical knowledge, bearing in mind that the regulations only specify the minimum requirements. Despite the fact that CPR standards specifying the reaction-to-fire performance of electric cables have been in force for over a year (two, if the transition period is taken into account), regulations as to the use of particular classes of cables have not been developed. This situation means that in Poland there is no clear specification of fire requirements for electric cables. In addition to the knowledge of the applicable requirements for electric cables and optical fibre, their testing methods and hazards related to wiring in buildings, technical knowledge is essential for the selection of wiring. An assumption can be made that, at least in the area of escape routes, electric cables and optical fibre with a higher reaction-to-fire performance should be used. Keywords: electric cables, optical fibre, reaction to fire, CPR, B mark, cable testing, flammability of cables, fire requirements for cables Type of article: review article

Received: 18.09.2018; Reviewed: 17.12.2018; Accepted: 21.12.2018;

Authors' ORCID IDs: W. Klapsa - 0000-0002-6481-587X; D. Małozięć - 0000-0003-4929-8656; A. Wolańska - 0000-0002-4609-8459;

Percentage contribution: W. Klapsa - 50\%; D. Małozięć - 30\%; A. Wolańska - 20\%;

Please cite as: BiTP Vol. 52 Issue 4, 2018, pp. 184-201, https://dx.doi.org/10.12845/bitp.52.4.2018.11;

This is an open access article under the CC BY-SA 4.0 license (https://creativecommons.org/licenses/by-sa/4.0/).

\section{АННОТАЦИЯ}

Цель: Основной целью данной статьи является рассмотрение требований пожарной безопасности к электрическим кабелям и оптоволокну. Дополнительная цель - это представление методов тестирования их характеристик воспламеняемости.

Введение: С 2016 года электрические и волоконно-оптические кабели считаются строительной продукцией. В связи с этим, при размещении на рынке, они, как и любой другой строительный продукт, подпадают под действие положений Регламента Европейского парламента и Совета Европы. В статье представлены требования к кабелям перед их допущением к обороту на европейском рынке (включая также на польском), а также проверка свойств этих продуктов в области пожарной безопасности. В связи с тем, что гармонизированный стандарт не распространяется на определенные группы кабелей (в основном в системах пожарной безопасности), в контексте этих групп обсуждались национальные требования, предъявляемые к их размещению на рынке. Статья также включает синтетический анализ национальных нормативных актов в области требований к электрическим и оптоволоконным кабелям в контексте противопожарной защиты.

Методология: Обзор правовых требований на европейском и национальном уровне в контексте допуска к реализации электрических или оптоволоконных кабелей. Был также проведен анализ правового статуса в Польше с точки зрения требований противопожарной защиты к электрическим или волоконно-оптическим кабелям, используемым в строительстве, а также методологий исследований, использованных для характеристики этих продуктов и оценки сопутствующей пожарной опасности.

Выводы: При выборе типа кабельной проводки для здания, помимо функциональных аспектов в виде электрических функций, следует также обратить внимание на пожарную опасность, которая заключается в большом скоплении кабелей в кабельных пучках. Обзор, представленный в статье, подтвердил, что не все вопросы регулируются законом, а в некоторых случаях регулируются неправильно. Поэтому проектировщики и оценщики по пожарной безопасности должны использовать свои собственные технические знания о кабелях, тем более что нормативные акты устанавливают только минимальные требования к этим продуктам. Несмотря на то, что требования Регламента Европейского парламента и Совета Европы относительно определения реакции на возгорание электрических кабелей существует более года (два, если считать переходный период), правила использования отдельных классов не разработаны, а это означает, что нет четкого сообщения о том, какие требования следует выдвигать к электрическим кабелям. В дополнение к знанию текущих требований к электрическим кабелям и волоконной оптике, способов их тестирования и рисков прокладки кабелей в здании, необходимы также технические знания при выборе кабелей. Следует предположить, что, по крайней мере, в зоне путей эвакуации следует использовать электрические кабели и оптические волокна тех типов, которые имеют более высокую степень реакции на возгорание.

Ключевые слова: электрические кабели, оптические волокна, реакция на возгорание, РЕП, знак В, испытание кабеля, воспламеняемость кабеля, требования к кабелю

Вид статьи: обзорная статья

Принята: 02.12.2018; Рецензирована: 17.12.2018; Одобрена: 21.12.2018;

Идентификаторы ORCID авторов: W. Klapsa - 0000-0002-6481-587X; D. Małozięć - 0000-0003-4929-8656; A. Wolańska - 0000-0002-4609-8459;

Процентное соотношение участия в подготовке статьи: W. Klapsa - 50\%; D. Małozięć - 30\%; A. Wolańska - 20\%;

Просим ссылаться на статью следующим образом: BiTP Vol. 52 Issue 4, 2018, pp. 184-201, https://dx.doi.org/10.12845/bitp.52.4.2018.11;

Настоящая статья находится в открытом доступе и распространяется в соответствии с лицензией CC BY-SA 4.0 (https://creativecommons.org/

licenses/by-sa/4.0/).

\section{Wprowadzenie}

Od ponad roku - po wielu latach ustaleń na szczeblu europejskim - obowiązują przepisy regulujące kwestię oceny kabli elektrycznych i światłowodów pod względem ich palności.

\section{Introduction}

The regulations laying down the rules for the flammability assessment of electric cables and optical fibre were adopted on the European scale more than a year ago, following many 
Stosowane są one przy wprowadzaniu tych wyrobów na rynek europejski. Przy obecnym stanie zaawansowania technologicznego budynków wykorzystanie kabli w jednym tylko obiekcie liczone jest w kilometrach bieżących. Pomimo że istnieje wymóg prowadzenia głównych ciągów instalacji elektrycznej poza mieszkaniami i pomieszczeniami przeznaczonymi na pobyt ludzi (w wydzielonych kanałach lub szybach instalacyjnych), to należy mieć na uwadze podstawowy przepis Działu VI warunków technicznych dla budynków [1], który wymaga zaprojektowania i wykonania urządzeń związanych z budynkiem w sposób zapewniający w razie pożaru ograniczenie rozprzestrzeniania się ognia i dymu w budynku oraz możliwość ewakuacji ludzi. Kable elektryczne i światłowody w razie wystąpienia pożaru mogą spowodować zagrożenia w postaci:

- eskalacji pożaru wskutek obecności dużej ilości materiału palnego,

- rozprzestrzeniania się ognia,

- wydzielania dużych ilości dymu,

- wydzielania się substancji toksycznych,

- wytwarzania agresywnego środowiska korozyjnego.

W związku z powyższym nie można lekceważyć kwestii bezpieczeństwa pożarowego w obiektach budowlanych, które z kolei uwarunkowane jest zastosowaniem wyrobów kablowych o odpowiednich cechach palności. Istnieje potrzeba przeprowadzenia analizy, czy stan prawny w sposób jednoznaczny reguluje tę kwestię.

\section{Obowiązujące przepisy prawa}

Kable elektryczne zasilania (elektroenergetyczne)', sterujące i telekomunikacyjne (komunikacyjne)² stanowią 31. grupę wyrobów budowlanych wymienioną w załączniku IV do rozporządzenia Parlamentu Europejskiego i Rady (UE) NR 305/2011(CPR) z dnia 9 marca 2011 r. ustanawiającego zharmonizowane warunki wprowadzania do obrotu wyrobów budowlanych i uchylającego dyrektywę Rady 89/106/EWG [2]. W związku z powyższym producenci kabli elektrycznych i światłowodów powinni dokonywać deklaracji właściwości użytkowych (DoP) zgodnie z normą zharmonizowaną, europejską oceną technicznej wyrobu, a także oznakowywać wyroby wymienione w DoP znakiem CE. W 2006 roku decyzją komisji nr 2006/751/WE ustanowiono oddzielne klasy odporności na działanie ognia dla kabli elektrycznych [3]. W roku 2015 została opublikowana i ogłoszona zharmonizowana norma wyrobu PN-EN 50575 [4], która została w pełni wdrożona z początkiem lipca 2017 roku (Dz. Urz. UE z 13.11.2015 r. 2015/C 378/03). Zgodnie z zapisami tej normy producenci mają obowiązek potwierdzić właściwości kabli elektrycznych i światłowodów w zakresie reakcji na ogień na podstawie wymagań normy klasyfikacyjnej PN-EN 13501-6 [5]. Mając na uwadze powyższe, wszystkie kable elektryczne stosowane w budownictwie powinny mieć potwierdzone właściwości pożarowe, a także powinny być dobierane odpowiednio do miejsca zastosowania - jak ma to miejsce w przypadku innych wyrobów budowlanych.

\footnotetext{
W polskim tłumaczeniu znajdują się dwie formy w zależności od aktu prawnego.

jw.
}

years of discussions. They apply to placing such products on the European market. At the current stage of technological advancement of buildings, any engineering structure contains kilometres of cables. Although it is required for the core part of the electrical system cables to be located outside flats and rooms intended for human occupation (in separate ducts or conduits), the basic regulation of Section VI of the technical requirements for buildings [1] must be borne in mind. It requires that devices connected with the building should be designed and produced in a manner that reduces the spread of fire and smoke within the building and facilitates egress. In the event of a fire, electric cables and optical fibre may cause such hazards as:

- the escalation of fire due to the presence of a large amount of flammable materials,

- the spread of fire,

- the release of large amounts of smoke,

- the release of toxic substances,

- the appearance of aggressive corrosive agents.

Considering the above, it is important not to neglect fire safety in civil structures, which largely depends on the use of cable products with specific flammability properties. There is a need to analyse whether this issue is clearly addressed in the current legislative framework.

\section{Legal regulation in force}

Power (Polish: zasilania, elektroenergetyczne)', control (sterujące) and communication (telekomunikacyjne, komunikacyjne) $)^{2}$ cables constitute Area 31 of construction products listed in Annex IV to Regulation (EU) No 305/2011 of the European Parliament and of the Council of 9 March 2011 laying down harmonised conditions for the marketing of construction products and repealing Council Directive 89/106/EEC [2]. Due to the above, electric cable and optical fibre manufacturers should draw up declarations of performance (DoP) in accordance with the harmonised standard and the product's European Technical Assessment, as well as provide the products listed in DoP with CE marking. In 2006 Commission Decision No 2006/751/EC laid down the separate classes of reaction-to-fire performance for electric cables [3]. The harmonised standard for products PNEN 50575 [4] was published in 2015 and fully implemented in early July 2017 (OJ EU of 13.11.2015, 2015/C 378/03). Pursuant to this standard, manufacturers must certify the reaction-to-fire performance properties of electric cables and optical fibre on the basis of classification standard PN-EN 13501-6 [5]. Taking the above into consideration, all electric cables used in construction should have certified fire performance and should be selected on the basis of their area of application, as for other construction products.

\footnotetext{
The Polish translation includes two forms, depending on the legislation.

2 See above.
} 
W celu omówienia wymagania dotyczącego stosowania odpowiednich kabli elektrycznych w obiektach budowlanych należy dokonać rozgraniczenia na:

I. Kable elektryczne i światłowodowe do ogólnych zastosowań;

II. Kable do dostaw energii elektrycznej, zastosowań telekomunikacyjnych oraz detekcji pożaru i alarmowania o pożarze w budynkach i innych obiektach budowlanych, których nadrzędnym celem jest zapewnienie ciągłości zasilania i/lub sygnału instalacji bezpieczeństwa, takich jak instalacje alarmowe, ewakuacyjne i przeciwpożarowe, zespoły kablowe (kabel plus mocowanie).

Pierwszą grupę wyrobów można zastosować w budynku po spełnieniu wymagań określonych w rozporządzeniu UE nr 305/2011 tj. opatrzeniu wyrobu deklaracją właściwości użytkowych wydaną przez producenta, zgodnie z przyjętym systemem oceny i weryfikacji stałości właściwości użytkowych wyrobu budowlanego i oznakowaniem znakiem CE [2].

W przypadku pozostałych dwóch grup mamy do czynienia z wyrobami wyłączonymi z normy zharmonizowanej PN-EN 50575, w tym służącymi zapewnieniu bezpieczeństwa publicznego lub ochronie zdrowia i życia oraz mienia. Wyroby te podlegają obowiązkowi oceny technicznej na poziomie krajowym zgodnie z rozporządzeniem Ministra Infrastruktury i Budownictwa z dnia 17 listopada 2016 r. w sprawie sposobu deklarowania właściwości użytkowych wyrobów budowlanych oraz sposobu znakowania ich znakiem budowlanym [6] oraz w zależności od przyjętego systemu oceny i weryfikacji stałości właściwości użytkowych, certyfikacji krajowej i/lub procesowi dopuszczenia do użytkowania w ochronie przeciwpożarowej (jeżeli zaliczone są do grupy 14.1 i 14.2 wyrobów wymienionych wykazie wyrobów służących zapewnieniu bezpieczeństwa publicznego lub ochronie zdrowia i życia oraz mienia) [7] .Dla tych wyrobów zastosowanie ma art. art. 9 pkt. 1 ustawy o wyrobach budowlanych [8]. Oznacza to, że można dokonać krajowej oceny technicznej wyrobu. Jednostki upoważnione do wydawania, uchylania i zmiany krajowej oceny technicznej są wyznaczone przez ministra właściwego ds. budownictwa, który monitoruje ich działania i kompetencje. Jednostką taką w odniesieniu do wyrobów budowlanych wykorzystywanych przez podmioty ochrony przeciwpożarowej do alarmowania o pożarze lub innym zagrożeniu oraz stosowanych do prowadzenia działań ratowniczych jest np. CNBOP-PIB. Krajową ocenę techniczną (KOT) udziela się na podstawie oceny właściwości użytkowych i przewidywanej trwałości zidentyfikowanego wyrobu budowlanego. Właściwości te potwierdza się na podstawie przedstawionych badań, obliczeń, oględzin, opinii ekspertów lub innych dokumentów, zgodnie z przepisami szczególnymi, np. techniczno-budowlanymi lub polskimi normami wyrobów [9]. Po uzyskaniu krajowej oceny technicznej producent w zależności od wskazanego systemu oceny może otrzymać krajowy certyfikat zgodności i po wystawieniu krajowej deklaracji właściwości użytkowych może wprowadzić wyrób do obrotu.

Wyroby z grupy II i III zostały także ujęte w wykazie wyrobów przywołanych w załączniku do rozporządzenia Ministra Spraw Wewnętrznych i Administracji w sprawie wykazu wyrobów służących zapewnieniu bezpieczeństwa publicznego
To discuss the requirement of using appropriate electric cables in civil structures, the cables should be divided into:

I. General-purpose electric cables and optical fibre;

II. Cables used for power supply, telecommunications, fire detection and signalling in buildings and other civil structures, the main purpose of which is to ensure the continuity of power supply and/or the operation of security systems, such as alarm, evacuation and fire protection systems. Cable systems (cable and fixing).

The first of these product areas can be used in buildings after complying with the requirements set out in Regulation EU No $305 / 2011$ i.e. providing a declaration of performance issued by the manufacturer in accordance with the adopted system for the assessment and verification of the constancy of performance of a construction product and CE marking [2].

For the remaining two areas, these are products excluded from harmonised standard PN-EN 50575, including products used for ensuring public security and the protection of health, life and property. These products are subject to the obligation to undergo technical assessment at the national level pursuant to the Regulation of the Minister of Infrastructure and Construction of 17 November 2016 on the manner of declaring the performance of construction products and the procedure of marking them with a construction mark [6] and depending on the adopted system for the assessment and verification of the constancy of performance, national certification and/or the process of product approval in fire protection (if they are included in areas 14.1 and 14.2 of the products on the list of products used for ensuring public security and the protection of health, life and property) [7]. Such products are subject to Article 9 (1) of the Act on Construction Products [8]. This means that a National Technical Assessment can be issued for the product. The bodies authorised to issue, revoke and amend the National Technical Assessment are designated by the Minister in charge of construction, who monitors their activities and competences. With regard to construction products used by fire protection entities for signalling fires or other hazards and used during rescue actions, such an entity is CNBOP-PIB (the Scientific and Research Centre for Fire Protection - National Research Institute). A National Technical Assessment (KOT) is issued on the basis of an assessment of performance and the expected durability of the identified construction product. These properties are verified on the basis of the presented tests, calculations, inspections, expert opinions or other documents, in accordance with specific provisions, e.g. technical and construction standards or Polish standards for products [9]. After obtaining a National Technical Assessment, the manufacturer, depending on the indicated assessment system, may obtain a National Certificate of Compliance and, following the issue of the National Declaration of Performance, may place the product on the market.

Products from groups II and II were also included on the list of products listed in the Appendix to the Regulation of the Minister of the Interior and Administration on the specification of products used to assure public safety or the protection of health and life and property, as well as issuance rules for certificates of admittance for the use of those products [7], which means that the manufacturer must obtain a relevant certificate 
lub ochronie zdrowia i życia oraz mienia, a także zasad wydawania dopuszczenia tych wyrobów do użytkowania [7], i co za tym idzie, producent przed wprowadzeniem ich do użytkowania musi uzyskać odpowiednie świadectwo dopuszczenia wydawane przez CNBOP-PIB. Wyroby te powinny spełniać wymagania techniczne określone w załączniku do rozporządzenia. Obecnie brak jest polskiej normy wyrobu dla kabli (nieobjętych normą PN-EN 50575) i zespołów kablowych. Należy więc uprzednio uzyskać krajową ocenę techniczną, która stanowi podstawę do udzielenia świadectwa dopuszczenia. Po uzyskaniu świadectwa dopuszczenia można wprowadzić wyrób do użytkowania.

Kable zasilania (elektroenergetyczne), sterujące i telekomunikacyjne są wyrobami budowlanymi, przy czym nie dokonano żadnego formalnego podziału kabli ze względu na zastosowanie (budownictwo ogólne czy systemy bezpieczeństwa). Taki podział wynika z zapisów normy PN-EN 50575, w której, w rozdziale 1 - „Wprowadzenie", pojawił się zapis, że wymagania normy nie dotyczą kabli elektrycznych, których najważniejszym celem jest zapewnienie ciągłości dostaw energii elektrycznej i/lub sygnału do instalacji alarmowych, dróg ewakuacji i instalacji gaśniczych [4]. Nie należy jednak tego interpretować w ten sposób, że kablom stosowanym w tych systemach nie stawia się wymagań dotyczących reakcji na ogień, tylko, że powinny one spełniać jeszcze dodatkowe kryteria wynikające z ich zastosowania końcowego.

Powyżej omówione zostały wymagania, które muszą spełnić kable elektryczne, jako wyrób budowlany, aby móc je wprowadzić na rynek. Poza wyżej wymienionymi kablom elektrycznym stawia się także wymagania stricte pożarowe. Podczas projektowania instalacji elektrycznych należy wziąć pod uwagę wymagania przepisów techniczno-budowlanych oraz rozważyć dobór kabli elektrycznych pod kątem ich zachowania w czasie pożaru (tj. czy wydzielają dużo ciepła, rozprzestrzeniają ogień, wydzielają dużą ilość dymu, są toksyczne lub wytwarzają agresywne środowisko dla elementów metalowych oraz czy powodują powstawanie kapiących płonących cząstek). Analiza przepisów krajowych pozwala stwierdzić, że obecnie nie ma jednolitych i precyzyjnych wymagań dla kabli elektrycznych. Funkcjonuje także wiele metod badawczych sprawdzania ich cechy ogniowych.

W rozporządzeniu Ministra Infrastruktury w sprawie warunków technicznych, jakim powinny odpowiadać budynki i ich usytuowanie [1] znajdują się ogólne wymagania dla instalacji elektrycznych, w tym kabli. Należy je tak dobierać, aby zapewnić ochronę przed pożarem (§180 ust. 2 [1]), a ciągi instalacji elektrycznej w budynkach mieszkalnych, zamieszkania zbiorowego i użyteczności publicznej należy wykonać zgodnie z polską normą PN-IEC 60364-5-52:2002 [10]. Warto zwrócić uwagę, że w obiegu jest również dostępny dokument harmonizacyjny o statusie polskiej normy PN-HD 60364-5-52:2011 ze zmianą A1, który wprowadza IEC 60364-5-52:2009.

W normie wskazano między innymi na konieczność zminimalizowania ryzyka rozprzestrzeniania się ognia przez oprzewodowanie. Można to osiągnąć poprzez spełnienie wymagań serii norm PN-EN 60332-1 [11] oraz PN-EN 60332-3 [12]. Pierwsza seria norm wskazuje metodę badania, które musi przejść każdy kabel elektryczny. Metoda ta sprawdza, jak zachowuje of admittance issued by CNBOP-PIB. These products should meet the technical requirements specified in the Appendix to the Regulation. Currently there is no Polish product standard for cables (not covered by standard PN-EN 50575) and cable systems. A National Technical Assessment must first be obtained, as it forms the basis for issuing a certificate of admittance. After obtaining the certificate of admittance, the product may be put into use.

Power, control and communication cables are construction products, although there is no formal division of cables by application (general construction or safety systems). Such a division results from the PN-EN 50575 standard, which, in Chapter 1 - "Introduction" provides that the requirements of the standard do not concern electric cables, the main purpose of which is to maintain the continuity of electric energy supplies and/or signal for alarm systems, evacuation routes and fire extinguishing systems [4]. However, this does not mean that cables used in these systems are not subject to requirements concerning reaction-to-fire performance, but that they should also comply with additional criteria resulting from their end use.

The requirements to be met by electric cables as a construction product to be placed on the market are discussed above. In addition to the above-mentioned requirements, electric cables must also comply with strictly fire-related regulations. The design process of electric systems should take into account the requirements of technical and construction regulations and consider the selection of electric cables on the basis of their behaviour during a fire (i.e. whether they release large amounts of heat, spread the fire, release large amounts of smoke, are toxic, create an aggressive environment for metal elements, or cause flaming droplets). An analysis of the national regulations demonstrates that there are currently no uniform and precise requirements for electric cables. There is also a variety of test methods used to determine their fire characteristics.

The Regulation of the Minister of Infrastructure on the technical conditions to be met by buildings and their location [1] contains general requirements for electric systems, including cables. Their selection should be based on fire protection ( $\$ 180$ (2)[1]) and electric system lines in residential buildings, multi-apartment residential buildings and public utility buildings should be made according to Polish standard PN-IEC 60364-5$52: 2002$ [10]. It should be noted that a harmonisation document having the status of a Polish standard, PN-HD 60364-5-52:2011 with amendment $A 1$, which introduces IEC 60364-5-52:2009, is also in circulation.

The standard includes the need to minimise the risk of fire spreading through wiring. This can be achieved by complying with the requirements of the PN-EN 60332-1 [11] and PN-EN $60332-3$ [12] series of standards. The former indicates the method of testing to which each electric cable must be subjected. This method tests the behaviour of a single insulated cable or duct during the vertical spreading of the flame. This method makes it possible to determine whether the insulation or coating material is a self-extinguishing material. The test involves the point application of an ignition source of $1 \mathrm{~kW}$ to the sample, 
się pojedynczy izolowany przewód lub kabel podczas pionowego rozprzestrzeniania się płomienia. Na podstawie tej metody można określić, czy materiał, z którego wykonana została izolacja lub powłoka, jest materiałem samogasnącym. Badanie polega na punktowym przyłożeniu źródła ognia o mocy $1 \mathrm{~kW}$ do badanej próbki, a następnie zmierzeniu długości spalenia na powierzchni kabla oraz obserwacji, czy nie występują kapiące, palące się cząstki [11]. Na rycinie 1 przedstawiono przykładowe badanie według opisanej metody. followed by the measurement of the cable surface's length of incineration and observation whether flaming droplets appear. Figure 1 presents an example test conducted according to the said method.

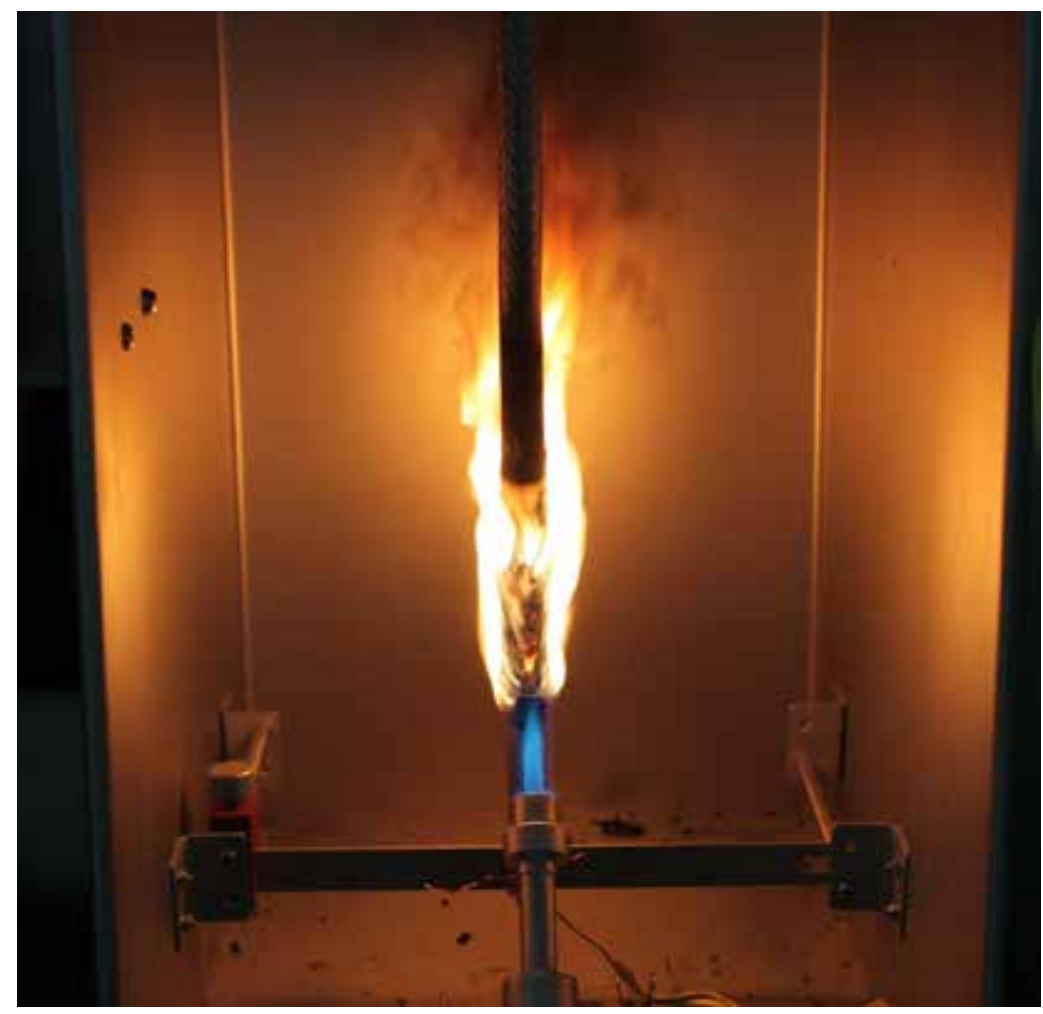

Rycina 1. Przykładowe badanie wg PN-EN 60332-1-2

Figure 1. Example test according to PN-EN 60332-1-2

Źródło: Opracowanie własne.

Source: Own elaboration.

Spełnienia wymagań drugiej z wymienionych norm badawczych wymaga się, gdy przewidywane jest wystąpienie w instalacji szczególnego zagrożenia. Wymaganie wskazano w normie w postaci uwagi do zapisu podstawowego. Metody badawcze wskazane w serii norm PN-EN 60332-3 dotyczą rozprzestrzeniania płomienia wzdłuż pionowo zamontowanych wiązek kabli lub przewodów. Stosuje się tam źródło ognia w postaci palnika o mocy 20,5 kW. Liczbę odcinków kabli wymaganych do badania określana jest za pomocą przelicznika objętości materiału palnego na 1 metr badanej wiązki, w zależności od tego, na jaką kategorię będzie badany wyrób. Rozróżnia się pięć kategorii od najlepszej do najgorszej: A F/R, A, B, C, D. Im lepsza kategoria kabla, tym więcej materiału palnego (objętościowo) przypada na metr badanej wiązki. Czas aplikacji źródła ognia również jest uzależniony od kategorii i wynosi 20 lub 40 min. Kabel elektryczny przechodzi pozytywnie próbę, gdy wysokość wypalenia nie przekracza $2,5 \mathrm{~m}$ od poziomu palnika.
The latter of the test standards must be complied with in systems with expected elevated fire hazards. The requirement is identified in the standard in the form of a comment to a primary entry. The test methods indicated in the PN-EN 60332-3 series of standards relate to the spreading of the flame along cable or duct bundles installed vertically. They make use of an ignition source in the form of a torch with a power of $20.5 \mathrm{~kW}$. The number of cable sections required to be tested is calculated according to the conversion factor of flammable material volume per 1 metre of the tested bundle, depending on the class to which the product is tested. There are five classes ranked from best to worst: A F/R, A, B, C, D. The higher the cable's class, the more flammable material (by volume) there is per one metre of the tested bundle. The duration of application of the ignition source also depends on the class and is equal to 20 or $40 \mathrm{~min}$ utes. Electric cables pass the test when the char height does not exceed $2.5 \mathrm{~m}$ from the torch level. 
OCENA ZGODNOŚCI

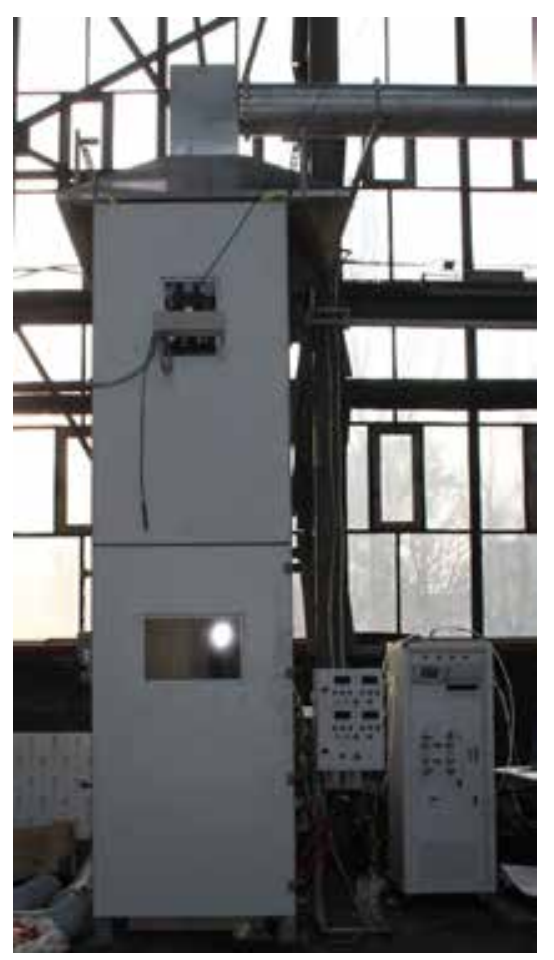

Rycina 2. Stanowisko badawcze wg serii PN-EN 60332-3 w CNBOP-PIB

Figure 2. Test stand according to PN-EN 60332-3 series in CNBOP-PIB

Źródło: Opracowanie własne.

Source: Own elaboration.

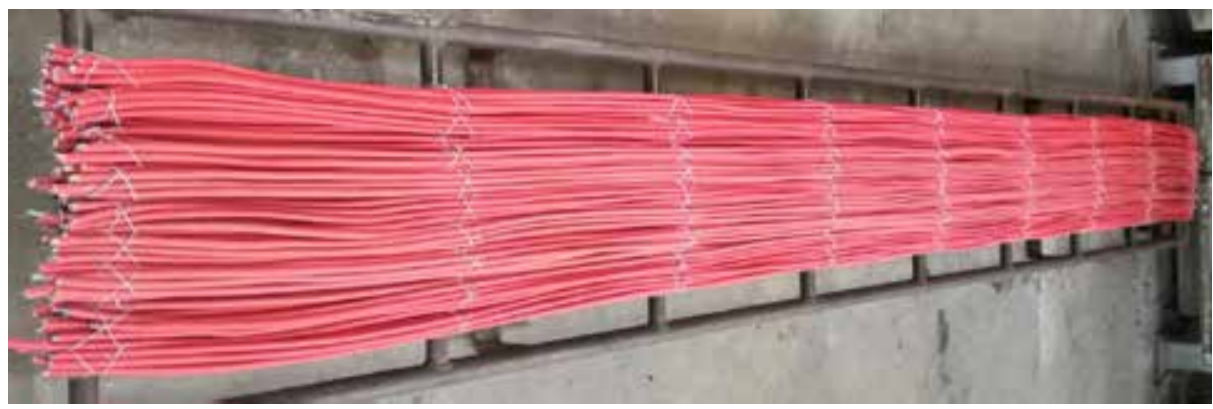

Rycina 3. Przykładowa próbka badawcza przed badaniem wg PN-EN 60332-3-22

Figure 3. An example of a test sample before testing according to PN-EN 60332-3-22

Źródło: Opracowanie własne.

Source: Own elaboration

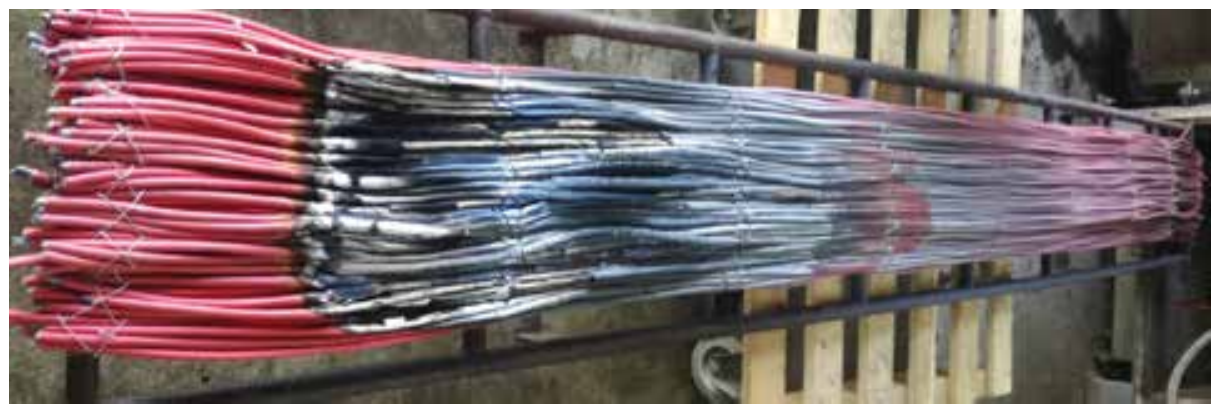

Rycina 4. Przykładowa próbka badawcza po badaniu wg PN-EN 60332-3-22

Figure 4. An example of a test sample after testing according to PN-EN 60332-3-22

Źródło: Opracowanie własne.

Source: Own elaboration. 
Kolejne zapisy na temat wymagań, jakie musi spełnić oprzewodowanie w obiekcie, znajdują się w normie PN-HD 60364-4-42 Ochrona przed skutkami oddziaływania cieplnego [13]. Wymagania te różnią się w zależności od oddziałujących na urządzenia elektryczne (w tym i kable)wpływów zewnętrznych, . które zostały określone w tablicy 51A w normie PN-HD 60364-5-51 [14]. W warunkach BD2 (mała gęstość zaludnienia, trudne warunki ewakuacji), BD3 (duża gęstość zaludnienia, łatwe warunki ewakuacji), BD4 (duża gęstość zaludnienia, trudne warunki ewakuacji) oprzewodowanie powinno prowadzić się poza drogami ewakuacji, chyba że prowadzone jest w odpowiednich osłonach lub obudowach. Dodatkowo droga kablowa powinna być możliwie najkrótsza, nie może rozprzestrzeniać ognia, a także powinna mieć ograniczoną intensywność wydzielania dymu. W normie wskazano, jako warunek nierozprzestrzeniania ognia, spełnienie wymagań wg PN-EN 60332-1-2 oraz serii PN-EN 60332-3. Kable spełniające wymóg $60 \%$ przepuszczalności światła wg PN-EN 61034-2 [15] traktowane są jako wyroby o ograniczonej intensywności wydzielania dymu. W warunkach BE2 (ryzyko ognia) wskazany jest warunek nierozprzestrzeniania ognia potwierdzony w ten sam sposób. W warunkach CB2 (rozprzestrzenianie ognia) kable powinny przejść próbę według serii norm PN-EN 60332-3. W pomieszczeniach, w których zagrożone są dobra znaczącej wartości, należy instalować kable i przewody z ulepszonymi cechami odporności ogniowej w przypadku zagrożenia ogniem, spełniające kryteria podane wg serii IEC 60331-1 [16] oraz IEC 60331-21 [17]. Pierwsza z norm jest kompilacją IEC 60331-12 i IEC 60331-31 (występujących w zbiorze polskich norm) i obecnie nie ma jeszcze statusu polskiej normy.

Warto zwrócić szczególną uwagę na zapis §258 ust. 2 warunków technicznych [1], który wprowadza zakaz stosowania materiałów i wyrobów budowlanych łatwo zapalnych na drogach komunikacji ogólnej służących do ewakuacji. Do tej pory nie zdefiniowano parametru łatwozapalności w stosunku do kabli i przewodów elektrycznych, pomimo że jest są one wyrami budowlanymi. Pewnym krokiem w tym kierunku jest stosowanie klasyfikacji reakcji na ogień wg PN-EN 13501-6 i próba odniesienia jej przez analogię do innych materiałów budowlanych, o czym będzie mowa w dalszej części artykułu. W kolejnym zapisie dotyczącym kabli i przewodów stosowanych w przestrzeni podpodłogowej oraz ponad sufitem podwieszanym, wykorzystywanej do wentylacji lub ogrzewania pomieszczenia (§259 ust. 2) znajduje się wymaganie cechy niepalności [1]. Bazując na normie klasyfikacyjnej PN-EN 13501-6 oraz w odniesieniu do wymagań stawianych innym materiałom budowalnym, za kabel lub przewód niepalny można by uznać wyrób, którego ciepło spalania jako całego wyrobu (poza częściami metalowymi) jest nie większe niż $2 \mathrm{MJ} / \mathrm{kg}$ - czyli w klasie reakcji na ogień Aca. Wskazanie innej klasy (np. B1ca) wymaga dodatkowej analizy wyników wielu badań

Poza ogólnymi wymaganiami dla przewodów i kabli określonymi przez rozporządzenie w sprawie warunków technicznych [1] pojawiają się również zapisy dotyczące przewodów i kabli stosowanych w systemach ochrony przeciwpożarowej oraz zespołów kablowych (§187 ust. 3). Jak już wcześniej wspomniano, wyroby te są badane według krajowych ocen technicznych wydawanych przez CNBOP-PIB. Poprzez zespoły należy rozumieć
Further provisions on the requirements to be met by wiring in a civil structure can be found in the PN-HD 60364-4-42 standard - Protection against thermal effects [13]. The requirements differ depending on the external impacts affecting the electric device (including cables), which were specified in Table 51A in the PN-HD 60364-5-51 standard [14]. Under BD2 conditions (low-density occupation, difficult evacuation conditions), BD3 (high-density occupation, easy evacuation conditions), BD4 (high-density occupation, difficult evacuation conditions), wiring routes should be installed outside escape routes, unless it is provided with suitable coatings or housings. The cable route should also be as short as possible, it should not contribute to spreading fire and it should also have a limited intensity of smoke release. As a condition for preventing the fire from spreading, the standard indicates compliance with the requirements of PN-EN 60332-1-2 and PN-EN 60332-3 series. Cables complying with the $60 \%$ light transmission requirement according to PN-EN 61034-2 [15] are treated as products with a limited smoke production rate. Under BE2 conditions (risk of fire) a requirement for fire spread prevention certified in the same way is indicated. Under CB2 conditions (spread of fire), cables should be subject to a test according to the PN-EN 60332-3 series of standards. In rooms where high-value goods are stored, cables and conduits with elevated fire resistance compliant with the criteria specified according to series IEC 60331-1 [16] and IEC 6033121 [17] should be installed. The former is a compilation of the IEC 60331-12 and IEC 60331-31 standards (present in the collection of Polish standards) and currently does not have the status of a Polish standard.

Particular attention should be drawn to $§ 258$ (2) of the technical conditions [1], which introduces a ban on using flammable construction materials and products along general routes used as escape routes. To date, the parameter of flammability in relation to electric cables and conduits has not been defined, even though these are construction products. Some progress towards this definition has been made by the application of the reaction-to-fire performance classification according to $\mathrm{PN}$ EN-13501-6 and an attempt to relate it by analogy to other construction materials, which is discussed further in this paper. Another provision regarding cables and conduits used in the sub-floor space and over the suspended ceiling used for ventilation or heating the room ( $\$ 259$ (2)) mentions the requirement of non-flammability [1]. On the basis of the PN-EN 13501-6 classification standard and with reference to the requirements imposed on other construction materials, a non-flammable cable or conduit can be defined as a product with a heat of combustion (for the whole product except its metal parts) no higher than $2 \mathrm{MJ} /$ $\mathrm{kg}$ - i.e. in the Aca reaction-to-fire performance class. Applying a different class (e.g. B1ca) would require performing additional analysis of the results of numerous tests.

In addition to the general requirements for cables and conduits specified by the Regulation on the technical conditions [1], there are also provisions regarding cables and conduits used in fire protection systems and regarding cable systems ( $\$ 187$ (3)). As already mentioned, these products are studied according to national technical assessments issued by CNBOP-PIB. 
przewody i kable elektryczne oraz światłowodowe wraz z ich zamocowaniami. Głównym badanym parametrem w przypadku zespołów kablowych jest zapewnienie ciągłości dostawy energii elektrycznej lub przekazu sygnału przez wymagany czas. Klasyfikacji zespołu kablowego wyrażonego w postaci parametru „E" ze wskazaniem minut $(30,60,90)$ dokonuje się na podstawie normy DIN 4102-12 [18]. Metoda ta jest wskazywana w krajowej ocenie technicznej jako bardziej adekwatna do badanego wyrobu niż przywołana w rozporządzenia [1] norma PN-EN 1363-1:2001. Przy czym w obu metodach krzywa nagrzewania w piecu badawczym jest tożsama. Należy w tym miejscu zwrócić uwagę na fakt, że krajowa ocena techniczna może być wydana oddzielnie na kabel, system mocowań (kablowych konstrukcji nośnych) oraz kompletny zespół kablowy spełniający kryterium podtrzymania funkcji „E” w określonym czasie. Nie oznacza to jednak możliwości "mieszania” zespołów kablowych. Odporność ogniową potwierdza się dla kompletnego zespołu kablowego, tj. konkretny kabel na konkretnej konstrukcji nośnej [18]. Rozdzielenie tych wyrobów spowodowane jest wymogiem uzyskania świadectwa dopuszczenia dla każdego z nich osobno, ponieważ w rozporządzeniu [7] regulującym kwestię wydawania świadectw dopuszczenia, wyroby te funkcjonują oddzielnie.

Warto zwrócić uwagę na fakt, że w 2016 roku do katalogu polskich norm wprowadzona została norma PN-EN 50577 [19], która również dotyczy badania zespołów kablowych i wprowadza nową klasyfikację "P” wyrażoną także w minutach. Niemniej jednak ta klasyfikacja nie ma jeszcze odniesienia w polskich przepisach. Dotyczy ona standardowych wykonań zespołów kablowych zawierających kable bądź inne przewody elektroenergetyczne o napięciu znamionowym nieprzekraczającym 600 V/1000 V lub światłowody. Same systemy mocowania kabli powinny być zgodne z EN 61537 Prowadzenie przewodów - Systemy korytek i systemy drabinek instalacyjnych [20]. W tym przypadku klasyfikacja dopuszcza mieszanie badanych wyrobów tj. różnych kabli i zamocowań posiadających klasyfikację „P”, przy czym przyjmuje się gorszą klasę dla całego zespołu kablowego.

W przypadku stosowania zespołów kablowych w pomieszczeniach chronionych stałymi wodnymi urządzeniami gaśniczymi, o czym mowa w $\S 187$ ust. 4 [1], powinny one być odporne na działanie wody. Nie wskazano jednak rodzaju badań potwierdzających ten parametr. W praktyce CNBOP-PIB przyjęto, że warunek ten jest spełniony w przypadku, gdy kabel zastosowany w zespole kablowym przechodzi pozytywnie badanie wg PN-EN 50200 [21] z użyciem wody (załącznik E do normy).

Jeszcze inne wymagania stawia się kablom i przewodom elektrycznym, o których mowa w $\$ 187$ ust. 5 [1]. Dotyczy to kabli wykorzystywanych w obwodach systemów alarmu pożarowego, oświetlenia awaryjnego i łączności. Powinny one się charakteryzować parametrem „PH" odpowiednim do czasu wymaganego działania. Klasę $\mathrm{PH}$ potwierdza się poprzez badanie według PN-EN 50200. Badanie to polega na sprawdzeniu, czy kabel zamocowany wskazanymi uchwytami do podłoża niepalnego, poddany działaniu źródła ognia w postaci palnika wytwarzającego płomień o temperaturze ok. $840^{\circ} \mathrm{C}$, jest zdolny do zachowania ciągłości obwodu. Na rycinie 5 pokazano przykładowe badanie.
Cable systems mean electric cables and conduits and optical fibre, along with their fixing. The primary parameter tested for cable systems is their ability to ensure the continuity of power supply and signal transmission over the required time period. Cable system classification expressed as parameter " $E$ " and the number of minutes $(30,60,90)$ is performed pursuant to the DIN 4102-12 standard [18]. This method is suggested in the national technical assessment as more suitable for the tested product than the PN-EN 1363-1:2001 standard mentioned in Regulation [1]. Both methods share the same heating curve in the test furnace. It should be pointed out that the national technical assessment may be issued separately for the cable, fixing system (for cable bearing systems) and a complete cable system meeting the criterion of maintaining function " $E$ " over a specific period of time. This does not mean that cable systems can be combined. Fire resistance is certified for the complete cable system, i.e. a specific cable on a specific cable bearing system [18]. The reason for the separation of these products is the requirement to obtain a certificate of admittance for each of them separately, as in Regulation [7] laying down the rules of issuing certificates of admittance these products are referred to separately.

It should be noted that in 2016 the collection of Polish standards was extended by the PN-EN 50577 standard [19], which also concerns cable system testing and introduces the new " $\mathrm{P}$ " classification, which is also expressed in minutes. However, this classification is not yet referred to in Polish regulations. It concerns standard implementations of cable systems containing electric cables or other conduits with a rated voltage of no more than $600 \mathrm{~V} / 1000 \mathrm{~V}$ or optical fibre. The fixing systems for cables, separately, should comply with EN 61537 Cable management - Cable tray systems and cable ladder systems [20]. In this case, the classification allows combining the tested products, i.e. various cables and fixing systems with the " $P$ " classification, with the lower class applied to the whole cable system.

Cable systems used in rooms protected by fixed water firefighting equipment, as mentioned in $\S 187$ (4)[1], should be water-resistant. However, the type of tests to confirm this parameter has not been provided. In CNBOP-PIB's practice, it was assumed that this condition is complied with where the cable used in a cable system successfully passes the test according to PN-EN 50200 [21] which uses water (Appendix E to the standard).

Still other requirements are imposed on electric cables and conduits mentioned in $\S 187$ (5)[1]. This is applicable to cables used in fire alarm system, emergency lighting and communication circuits. They should be characterised by the " $\mathrm{PH}^{\text {" param- }}$ eter applicable to the duration of the required operation. The $\mathrm{PH}$ class is confirmed by a test conducted according to PN-EN 50200. This test involves verifying whether the cable fixed with the indicated handles to a non-flammable base, when subject to an ignition source in the form of a torch producing a flame with a temperature of $840^{\circ} \mathrm{C}$, manages to maintain circuit continuity. Figure 5 shows an example test. 


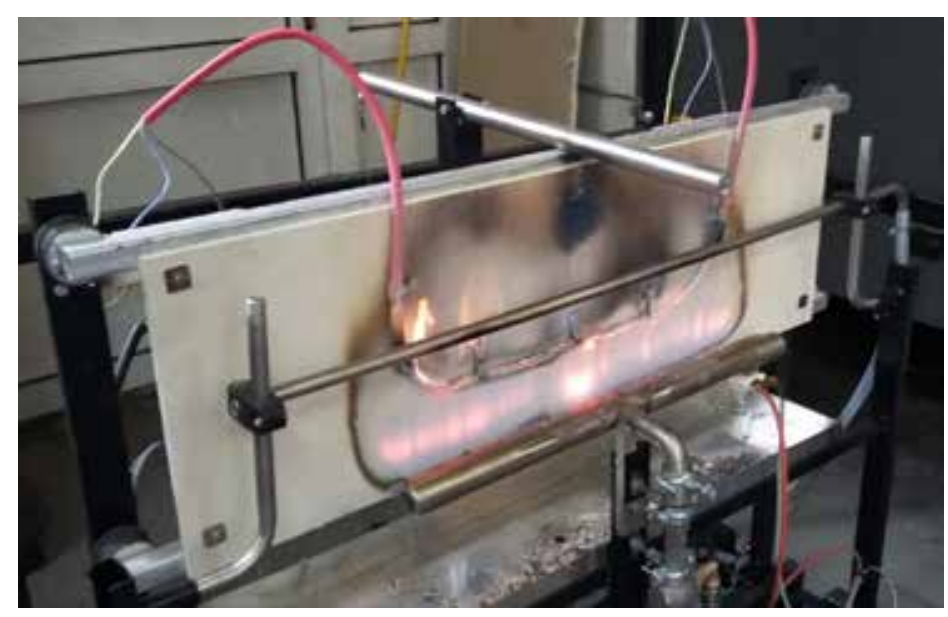

Rycina 5. Przykładowy test wg PN-EN 50200 w CNBOP-PIB

Figure 5. Test according to PN-EN 50200 in CNBOP-PIB

Żródło: Opracowanie własne.

Source: Own elaboration.

Krajowa ocena techniczna dla kabli przeznaczonych do stosowania w systemach służących do ochrony przeciwpożarowej - poza omówionymi powyżej testami - może stawiać jeszcze wymóg pozytywnego wyniku badań według norm: PN-EN 60332-1-2, PN-EN 60332-3, PN-IEC 60331-21, PN-EN 61034-2, PN-EN 60754-1(w przypadku kabli bezhalogenowych), PN-EN 60754-2 i PN-EN 50362. Norma PN-EN 50362 [22] dotyczy badania na klasę PH kabli o średnicach powyżej $20 \mathrm{~mm}$. Norma ta nie została ujęta w wykazie norm w załączniku do rozporządzenia w sprawie warunków technicznych [1], pomimo że często takie kable są stosowane w obiekcie. Dodatkowo dla tych kabli nie przewiduje się testu z wodą, jak ma to miejsce w przypadku kabli o średnicy poniżej $20 \mathrm{~mm}$. Obecnie trwają również prace nad nowelizacją normy klasyfikacyjnej EN 13501-3, która wprowadzi dodatkowe ograniczenie klasyfikacji $\mathrm{PH}$ dla kabli o przekroju żyły do $2,5 \mathrm{~mm}^{2}$.

Wymagania pożarowe dla przewodów i kabli elektrycznych zostały zawarte również w innych przepisach. W rozporządzeniu w sprawie warunków technicznych, jakim powinny odpowiadać obiekty budowlane metra i ich usytuowanie [23], w załączniku nr w punkcie 11 określono, że "[k]able, przewody oraz ich osłony zainstalowane wewnątrz tunelu lub stacji metra powinny być, co najmniej klasy reakcji na ogień B-s3, d0, a produkty ich rozkładu termicznego o kwasowości mniejszej niż pH 4,3". Określona klasa reakcji na ogień dotyczy innych wyrobów budowlanych niż kable i przewody elektryczne, dla których obecnie funkcjonuje klasyfikacja odrębna. Zapis ten wymaga jak najszybszej korekty. Wskazana klasa może być wymagana np. dla osłon kablowych. Zapis ten w poprawnym brzmieniu powinien wskazywać klasę reakcji na ogień B2ca-s3, d0. Parametr kwasowości w obecnym kształcie zapisu jest błędny. Kwasowość definiuje się za pomocą klasy a1, a2 lub a3, przy czym ważna jest również konduktywność. Dodatkowo określenie, że pH ma być mniejsze niż 4,3 oznacza stosowanie kabli, których produkty rozkładu są bardzo agresywne, czyli w klasie a3, a jednocześnie nie dopuszcza się stosowania kabli o lepszych właściwościach (produkty
The national technical assessment for cables designed for use in fire protection systems - in addition to the tests described above - may also require the positive result of tests conducted according to the following standards: PN-EN 60332-1-2, PN-EN 60332-3, PN-IEC 60331-21, PN-EN 61034-2, PN-EN 60754-1 (for halogen-free cables), PN-EN 60754-2 and PN-EN 50362. The PN-EN 50362 standard [22] concerns the PH class testing of cables with diameters over $20 \mathrm{~mm}$. This standard has not been included on the list of standards in the appendix to the Regulation on the technical conditions [1], although such cables are often used in civil structures. In addition, no water tests are provided for them, as is the case for cables with a diameter below $20 \mathrm{~mm}$. There is work in progress on the amendment of the EN 13501-3 classification standard, which will introduce an additional limitation on the $\mathrm{PH}$ classification for cables with a conductor cross-sectional area of $2.5 \mathrm{~mm}^{2}$.

The fire requirements for electric cables and conduits were also included in other regulations. Section 11 of the Appendix to the Regulation on the technical conditions to be met by civil structures of the metro and their location [23] provides that "[c] ables, conduits and their coverings installed inside a tunnel or metro station should have at least the B-s3, d0 reaction-to-fire performance class and their thermal decomposition products should have an acidity lower than $\mathrm{pH}$ 4.3. A specific reaction-to-fire performance class concerns other construction products than electric cables and conduits, for which a separate classification is currently in force. This provision should be corrected as soon as possible. The indicated class may be required e.g. for cable coverings. In its correct form, this provision should indicate the reaction-to-fire performance class B2ca-s3, d0. The acidity parameter is incorrect in its current form. Acidity is defined using the a1, a2 or a3 class and conductivity is also of importance. In addition, the provision that $\mathrm{pH}$ should be lower than 4.3 leads to the use of cables with highly aggressive decomposition products, i.e. a3, and does not allow the use of cables with better performance characteristics (less aggressive 
spalania mniej agresywne). Stąd poprawnym zapisem byłoby "o kwasowości nie mniejszej niż pH 4,3".

W rozporządzeniu w sprawie warunków technicznych, jakim powinny odpowiadać drogowe obiekty inżynierskie i ich usytuowanie [24] znajdujemy dwa zapisy dotyczące wymagań pożarowych dla kabli i przewodów elektrycznych, tj.: „§320 przewody i kable umieszczone w obiektach inżynierskich powinny mieć cechę nierozprzestrzeniania ognia" oraz "§321 ust. 1c [u]rządzenia $i$ instalacje stanowiące istotne $z$ punktu widzenia bezpieczeństwa wyposażenie tunelu powinny być wykonane w sposób zapewniający ich funkcjonowanie w warunkach pożaru przez wymagany czas". W obu przypadkach nie sprecyzowano wymagań. W odniesieniu do §320 należy uznać, że w pojedynczy przewód powinien spełnić wymagania PN-EN 60332-1-2, a w wiązka kabli odpowiednie wymaganie z serii PN-EN 60332-3. Jeżeli chodzi o §321 ust. 1c, można wymóg ten rozpatrywać w kontekście potrzeby zapewnienia zasilania lub sterowania poprzez zespół kablowy i stawiać wymóg klasy „E” lub pojedynczy kabel z mocowaniami i stawiać wymóg klasy „PH" o odpowiednich czasach. W rozporządzeniu Komisji UE nr 1303/2014 [21] odkrytym kablom elektrycznym w tunelach kolejowych o długości ponad 1 km stawia się wymóg minimalnej klasy B2CA, s1a, a1 zgodnie z przywołaną powyżej normą klasyfikacyjną.

\section{Zagrożenia i badania}

Jak wynika z przeprowadzonej powyżej analizy przepisów, na płaszczyźnie wymagań pożarowych dla przewodów i kabli elektrycznych jest mało precyzyjnych zapisów. Przepisy nie są spójne oraz zawierają błędy. Przy projektowaniu bezpieczeństwa pożarowego obiektów w kwestii kabli elektrycznych należy kierować się nie tylko zapisami przepisów, ale również wiedzą techniczną lub podejściem inżynierskim. W celu doboru odpowiedniego oprzewodowania warto zapoznać się z zagrożeniami, jakie one powodują oraz metodami badawczymi, które w lepszy sposób zobrazują właściwości palności kabli i przewodów. Z punktu widzenia początkowego okresu rozwoju pożaru najistotniejsza jest kwestia określenia reakcji na ogień, jak to ma to miejsce w przypadku innych materiałów budowlanych oraz cech dodatkowych, takich jak: dymotwórczość, kwasowość i toksyczność. Parametry te powinien mieć zdefiniowany każdy przewód czy kabel elektryczny wprowadzany do obrotu. Poniżej przedstawiono zagrożenia pożarowe oraz metody badawcze określające stopień zagrożenia, które będą składać się na pełną klasyfikację reakcji na ogień wg PN-EN 13501-6 tj.:

- PN-EN 60332-1-2;

- PN-EN 50399;

- PN-EN 61034-2;

- PN-EN 60754-2;

oraz inne ważne pod kątem oceny zagrożeń powodowanych przez kable w czasie pożaru.

Najważniejszym zagrożeniem z punktu widzenia ewakuacji ludzi, jakie występuje podczas pożaru kabli i przewodów elektrycznych, jest wydzielanie toksycznych gazów oraz dymów ograniczających widoczność. Poza badaniem zawartości ha- incineration products). Therefore, the correct provision would be "a pH no lower than 4.3."

The Regulation on the technical conditions to be met by road civil engineering structures and their location [24] features two provisions involving fire requirements for electric cables and conduits, i.e.: "§320 cables and conduits located in engineering structures should prevent fire spreading" and "§321 (1c) [d] evices and systems constituting important safety equipment of a tunnel should be fitted in a manner which guarantees that they remain operational during a fire for a required period of time." In both cases no requirements were specified. With regard to $\S 320$, it should be concluded that a single conduit should comply with the requirements of PN-EN 60332-1-2, and the cable bundle - with the relevant requirement of the PN-EN 60332-3 series. As for $\S 321$ (1c), this requirement may be seen in the context of the need to provide power or control by a cable system (with the " $E$ " class requirement) or by a single cable with fixings (with the " $\mathrm{PH}$ " class requirement) for appropriate periods of time. Pursuant to Regulation (EU) No 1303/2014 [21] exposed electric cables in railway tunnels of more than $1 \mathrm{~km}$ in length must fulfil as a minimum the requirements of classification B2CA, sla, a1, as per the above-mentioned classification standard.

\section{Hazards and tests}

On the basis of the above analysis of the regulations, it can be concluded that there is a shortage of accurate provisions with regard to the fire requirements for electric cables and conduits. The regulations are inconsistent and contain errors. When designing the fire safety of civil structures in the aspect of electric cables, one should not only follow the content of the regulations, but also draw on one's technical expertise and apply an engineering approach. To select the suitable wiring, the engineer should consider their potential hazards and the test methods which can better identify the flammability properties of cables and conduits. In the context of the early period of development of a fire, the most important issue is to define reaction-to-fire performance, as with other construction materials, and such additional properties as smoke density, acidity and toxicity. These parameters should be defined for every electric cable or conduit placed on the market. Below is a presentation of the fire hazards and test methods to determine the hazard level, which will comprise the full classification of reaction-to-fire performance according to PN-EN 13501-6, i.e.:

- PN-EN 60332-1-2;

- PN-EN 50399;

- PN-EN 61034-2;

- PN-EN 60754-2;

and other having importance for the assessment of hazards caused by cables during a fire.

In the context of the evacuation of people, the most important hazard during a fire of electric cables and conduits is the release of toxic gas and smoke which hinders visibility. Barring the test for hydrogen halide content, no other test methods are 
logenowodorów nie wskazuje się innych metod badawczych w zakresie toksyczności dla kabli elektrycznych ${ }^{3}$. Badanie to wykonuje się wg PN-EN 60754-1 [25] i polega ono na spaleniu materiału palnego pobranego z odcinka kabla i określeniu zawartości halogenowodrów w postaci kwasu halogenowego w mg/g. Przyjęło się na rynku, że kable bezhalogenowe o niskiej emisyjności dymów nie są trujące [15]. Wydzielanie dużych ilości dymu przez kabel stanowi poważne zagrożenie podczas ewakuacji. Badanie tego zjawiska wykonuje się wg PN-EN 50399 [26] oraz dodatkowo PN-EN 61034-2. Badanie wg PN-EN 61034-2 polega na umieszczeniu kabli o długości $1 \mathrm{~m}$ nad źródłem ognia (mieszanina alkoholi) i zmierzeniu spadku przepuszczalności światła w komorze testowej o wymiarach $3 \times 3 \times 3 \mathrm{~m}$. To proste badanie dobrze ukazuje, jak dużo dymu może wydzielić niewielka ilość kabli. W tabeli 1 poniżej zamieszczone zostały przykładowe wyniki minimalnej przepuszczalności światła dla wybranych kabli, a na rycinie 6 przykładowe badanie. indicated for the toxicity of electric cables ${ }^{3}$. This test, performed according to PN-EN 60754-1 [25], involves the incineration of a flammable material collected from a cable section and the determination of hydrogen halide content in the form of halogen acid in $\mathrm{mg} / \mathrm{g}$. The general consensus on the market is that halogen-free cables with low smoke emission are not toxic [15]. The release of large amounts of smoke by a cable constitutes a serious hazard during evacuation. This phenomenon is tested according to PN-EN 50399 [26] and, additionally, PN-EN 61034-2. The test according to PN-EN 61034-2 involves placing $1 \mathrm{~m}$ long cables over an ignition source (a mixture of alcohols) and measuring the decrease in light transmission in a $3 \times 3 \times 3 \mathrm{~m}$ test chamber. This simple test provides a clear view of how much smoke can be produced by a small section of a cable. Table 1 below provides example results for minimum light transmission in selected cables, and Figure 6 presents an example test.

Tabela 1. Wyniki minimalnej przepuszczalności światła w badaniu wg PN-EN 61034-2

Table 1. The results of the minimum light transmission in the test according to PN-EN 61034-2

\begin{tabular}{cc}
\hline Rodzaj kabla / Cable type & Min. przepuszczalność światta / Min. light transmission [\%] \\
\hline HDGs 2 × 4,0 / HDGs 2 × 4.0 & $86,02 / 86.02$ \\
\hline H2XH-J 4 × 4,0 / H2XH-J 4 × 4.0 & $85,7 / 85.7$ \\
\hline YnKYżo 4 × 1,5 / YnKYżo 4 × 1.5 & $7,18 / 7.18$ \\
\hline YnYKSYekw 7 × 2 × 0,8 / YnYKSYekw 7 × 2 × 0.8 & $16,5 / 16.5$ \\
\hline YKXS & $3,57 / 3.57$ \\
\hline
\end{tabular}

Źródło: Opracowanie własne.

Source: Own elaboration.

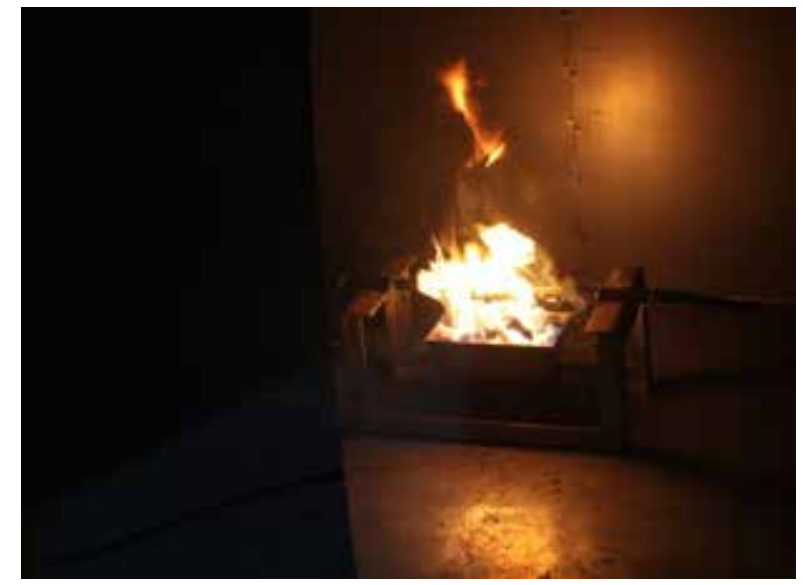

Rycina 6. Przykładowe badanie wg PN-EN 61034-2 w CNBOP-PIB

Figure 6. Example test according to PN-EN 61034-2 in CNBOP-PIB

Źródło: Opracowanie własne.

Source: Own elaboration.

Wcześniej był omawiany parametr rozprzestrzeniania ognia, który jest również składową reakcji na ogień. Jest on jednak inaczej oznaczany, niż ma to miejsce w przypadku serii norm

3 Niektóre ośrodki badawcze wykonują badania toksyczności materiałów, z których wykonane są kable i przewody elektryczne wg ISO 19700. Obie metody nie są wskazywane przy klasyfikacji reakcji na ogień.
The parameter discussed previously was the spread of fire, which is also a component of reaction-to-fire performance. However, it is determined in a different manner than in the case

Some testing centres conduct toxicity tests of materials used for the production of electric cables and conduits as per ISO 19700. Neither method is indicated in the reaction-to-fire performance classification. 
PN-EN 60332-3. Znajomość klasy reakcji na ogień dostarcza nam informacji, jak szybko materiał ulega zapaleniu, jak szybko się spala, ile wydziela ciepła podczas spalania oraz jak bardzo rozprzestrzenia ogień. Badanie tych cech wykonuje się wg PN-EN 50399 [26]. W metodzie tej do odpowiedniej ilości kabli o długości 3,5 m ułożonych w pionową wiązkę w komorze testowej o wymiarach $1 \times 2 \times 4 \mathrm{~m}$ przykłada się źródło ognia w postaci palnika o mocy 20,5 kW lub 30 kW (w zależności od pożądanej klasy). Podczas badania analizuje się ilość zużytego tlenu oraz produkcję $\mathrm{CO}_{2}$ i po odpowiednim przeliczeniu uzyskuje się wyniki (m.in. FIGRA, peak HRR tak jak ma to miejsce w przypadku badań SBI wg PN-EN 13823). Dodatkowo analiza osłabienia światła w kanale odciągowym pozwala na otrzymanie danych na temat dymotwórczości. Na podstawie takich samych parametrów określana jest klasa reakcji na ogień innych materiałów budowlanych. Po zakończeniu badania dokonuje się pomiaru wysokości zniszczenia kabli charakteryzującej rozprzestrzenianie ognia. Pomimo że badanie co do zasady jest bardzo podobne do badania rozprzestrzeniania płomienia przez wiązkę kabli wg serii PN-EN 60332-3, to przekazuje znacznie więcej informacji na temat badanego wyrobu. Daje również podstawy do porównań z innymi materiałami budowlanymi. Ze tego względu metoda ta jest rekomendowana obecnie jako podstawowe badanie przy określaniu reakcji na ogień kabli elektrycznych. Na rycinach 7 i 8 pokazano, jak dużo dymu może wydzielać się podczas badania oraz jak bardzo rozprzestrzenia się płomień po wiązce kabli. of the PN-EN 60332-3 series of standards. Knowing the reaction-to-fire performance class means knowing how fast a material ignites and how fast it burns, how much heat it releases during incineration and how much it contributes to the spread of fire. These properties are tested according to PN-EN 50399 [26]. In this method, an ignition source in the form of a torch with a power of $20.5 \mathrm{~kW}$ or $30 \mathrm{~kW}$ (depending on the desired class) is applied to an appropriate amount of cable material with a length of $3.5 \mathrm{~m}$ laid in a vertical bundle in a $1 \times 2 \times 4 \mathrm{~m}$ test chamber. The test involves the analysis of the amount of oxygen consumed and $\mathrm{CO}_{2}$ generation, after which calculations are performed to obtain the results (including FIGRA and peak HRR, as in the case of SBI tests according to PN-EN 13823). In addition, an analysis of the decrease in light transmission of the extraction duct allows obtaining data on smoke density. The reaction-to-fire performance of other construction materials is determined using the same parameters. After the test is completed, measurements of the height of and damage to cables characterising the spread of fire are performed. Although the test is in principle very similar to the test of flame propagation on cable bundles according to the PN-EN 60332-3 series, it provides much more information on the tested product. It also provides a basis for comparisons with other construction materials. Due to this, this method is currently recommended as the primary test to determine the reaction-to-fire performance of electric cables. Figures 7 and 8 show how much smoke can be released during the test and how much the flame propagates on the cable bundle.

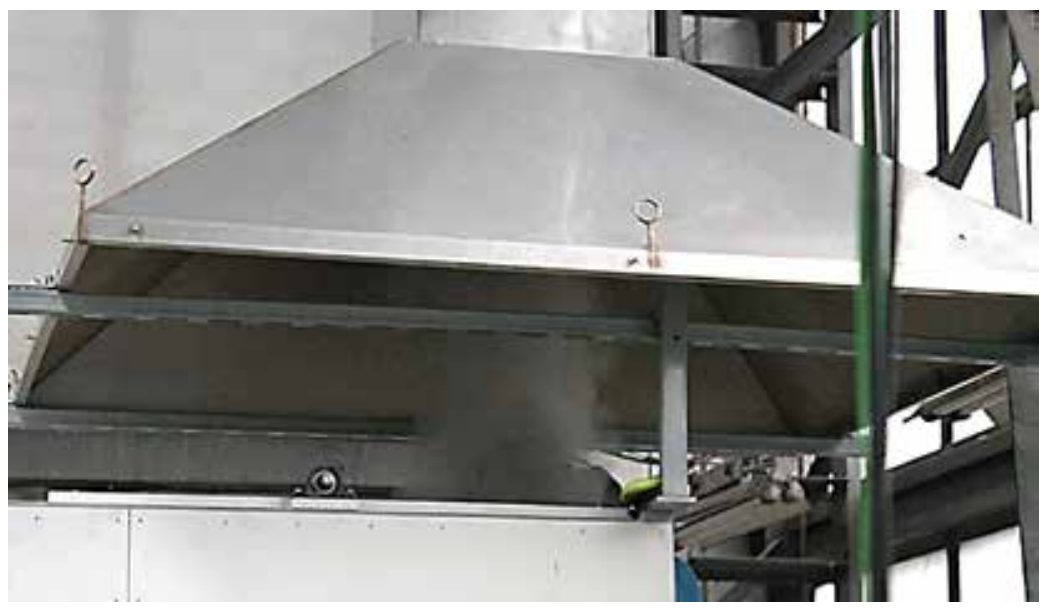

Rycina 7. Wydzielanie dymu przez kabel YnKYżo podczas badania wg PN-EN 50399

Figure 7. Release of smoke by the cable YnKYżo during the test according to EN 50399

Źródło: Opracowanie własne.

Source: Own elaboration.

Warto zwrócić uwagę na fakt, że kable elektryczne tzw. ognioodporne, stosowane w systemach ochrony przeciwpożarowej, niekoniecznie muszą mieć wysoką klasę reakcji na ogień, co pokazały m.in. testy przeprowadzone w CNBOP-PIB. Badaniu wg PN-EN poddano kable z grupy HDGs $\mathrm{PH} 90$. Poniżej w tabeli 2 zostały zestawione wyniki dla dwóch rodzajów kabli HDGs.
It should be pointed out that electric cables described as fire-resistant cables which are used in fire protection systems do not necessarily have a high class of reaction-to-fire performance, as determined e.g. by tests conducted by CNBOP-PIB. The test according to the PN-EN standard was performed on HDGs PH 90 cables. The table below lists the results for two types of HDGs cables. 


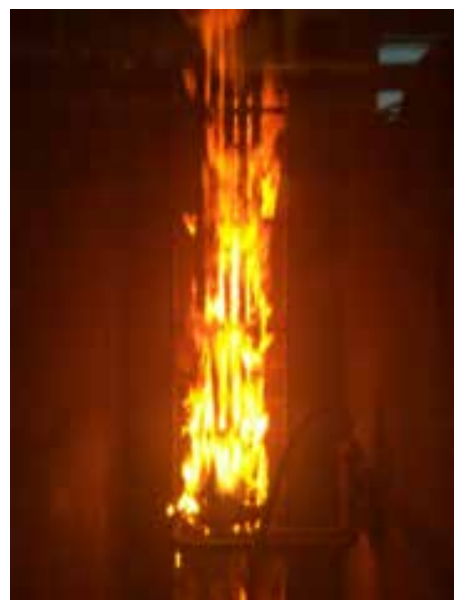

Rycina 8. Spalanie kabla bezhalogenowego wykonanego z polimeru, 0,6/1 kV podczas badania wg PN-EN 50399 Figure 8. Combustion of a halogen-free cable made from polymer, $0.6 / 1 \mathrm{kV}$ when tested according to DIN EN 50399 Źródło: Opracowanie własne.

Source: Own elaboration.

Tabela 2. Wyniki otrzymane w badaniu wg PN-EN 50399

Table 2. The results obtained in the test according to PN-EN 50399

\begin{tabular}{cccccc}
\hline $\begin{array}{c}\text { Rodzaj kabla } \\
\text { / Cable type }\end{array}$ & FIGRA [W/s] & Peak HRR $[\mathrm{kW}]$ & THR $_{1200}$ [MJ] & FS [m] & KLASA / CLASS \\
\hline $\begin{array}{c}\text { HDGsżo } 7 \times 1,0 \\
\text { / HDGsżo } 7 \times 1.0\end{array}$ & $142,5 / 142.5$ & $37,4 / 37.4$ & $16,7 / 16.7$ & $2,1 / 2.1$ & $\mathrm{D}_{\mathrm{ca}} \mathrm{s} 1$ \\
\hline $\begin{array}{c}\text { HDGs } 2 \times 4,0 \\
\text { / HDGs } 2 \times 4.0\end{array}$ & $90,9 / 90.9$ & $16,2 / 16.2$ & $11,8 / 11.8$ & $0,9 / 0.9$ & $\mathrm{~B}_{\mathrm{ca}} \mathrm{s} 1$ \\
\hline
\end{tabular}

Źródło: Opracowanie własne.

Source: Own elaboration.

Określenie klasy reakcji na ogień tego rodzaju kabli jest o tyle istotne, że często w pomieszczeniu nadzoru znajduje się bardzo duża ilość tych kabli. Zdarza się, że trasy kablowe przebiegają w przestrzeni podsufitowej i mogą stanowić poważne zagrożenie w czasie pożaru. Przykład nagromadzenia dużej ilości kabli ognioodpornych pokazano na rycinie nr 9.
Determining the reaction-to-fire performance class of this type of cable is important because control rooms usually feature a very large amount of such cables. There are cases where cable routes run in the sub-ceiling space and can pose a significant risk during fire. Figure 9 presents an example of the accumulation of a large number of fire-resistant cables.

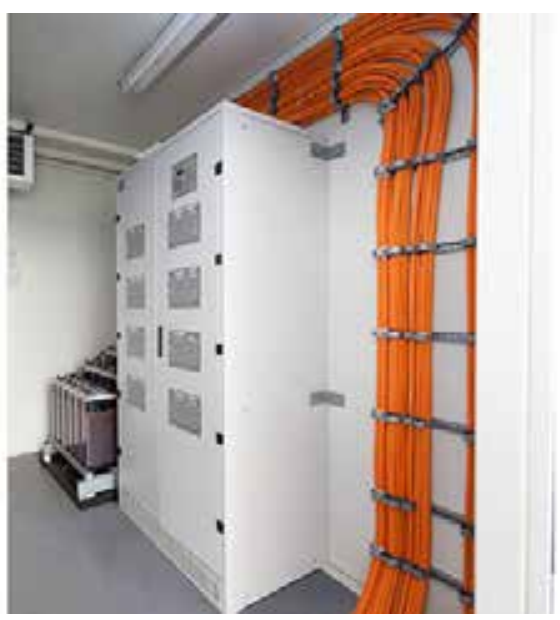

Rycina 9. Przykład nagromadzenia dużej ilości kabli ognioodpornych w pomieszczeniu

Figure 9. An example of the accumulation of a large number of fire-resistant cables in a room

Source: http://www.denios.pl/. 
Na kolejnych rycinach 10 i 11 pokazane są skutki pożaru, który rozprzestrzenił się po wiązkach kabli elektrycznych o słabych właściwościach w zakresie reakcji na ogień.
The following Figures 10 and 11 show the effects of a fire which has spread along electric cable bundles with poor reaction-to-fire performance properties.

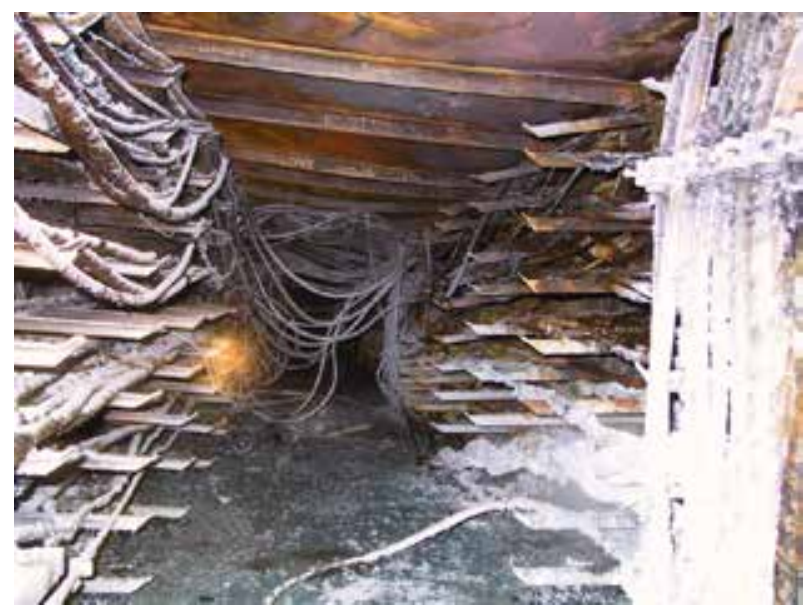

Rycina 10. Skutki pożaru wiązek kabli elektrycznych

Figure 10. The impact of fire on electric cable bundles

Źródło: Materiały ZEPAK.

Source: ZEPAK materials.

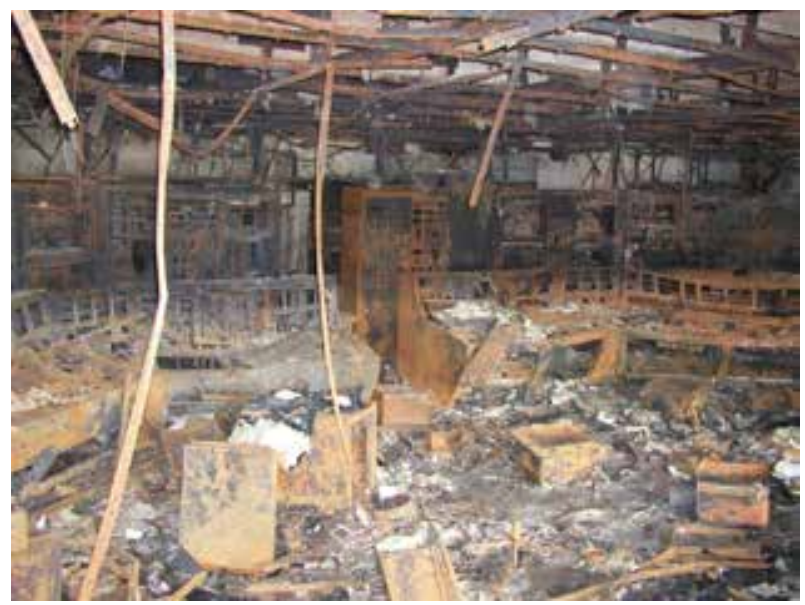

Rycina 11. Skutki pożaru w nastawni w elektrowni

Figure 11. The effects of a fire in the power plant's control room

Źródło: Materiały ZEPAK.

Source: ZEPAK materials.

Ostatnim badaniem wartym uwagi, które jest wymagane do pełnej klasyfikacji reakcji na ogień wg PN-EN 13501-6, jest badanie kwasowości i konduktywności gazów powstałych ze spalania kabli elektrycznych. Badanie wykonuje się wg PN-EN 60754-2 [25] i polega na spaleniu części niemetalowych próbek kabla, a następnie określeniu pH i konduktywności wody po przepuszczeniu przez nią powstałych gazów ze spalenia tej próbki. Wiedza na temat, jaką kwasowość posiada dany przewód lub kabel jest niezbędna w momencie projektowania oprzewodowania w pomieszczeniach, w których znajdują się elementy metalowe wrażliwe na korozję. W przypadku pożaru kabli wytwarzających agresywne środowisko wzrastać mogą starty pożarowe. Związane jest to z możliwą koniecznością wymiany elementów metalowych lub uszkodzenia urządzeń, pomimo że nie były one poddane bezpośredniemu działaniu ognia. Na rycinie 12 pokazana
The last notable test which is required to perform a complete reaction-to-fire performance classification according to PN-EN 13501-6 involves the study of acidity and conductivity of the gases produced during the incineration of electric cables. This test is performed according to PN-EN 60754-2 [25] and involves the incineration of a part of the non-metallic samples of the cable, followed by the determination of the $\mathrm{pH}$ and conductivity of water after the gases generated from the incineration of the sample are passed through it. Knowledge of the acidity of a given cable or conduit is necessary in the process of designing the wiring in rooms containing corrosion-sensitive metal elements. The combustion of cables which create an aggressive environment may lead to increased fire damage. This is connected with the potential necessity to replace the metal elements or damaged devices, even when they have not 
jest komora badawcza przed rozpoczęciem i po wykonaniu kilku testów. Jak widać, wystąpiła znaczna korozja, pomimo wykonania komory z blachy kwasoodpornej. been directly affected by fire. Figure 12 presents the test chamber before and after several tests have been performed inside. Considerable corrosion is visible, even though the chamber is made of acid-proof steel.

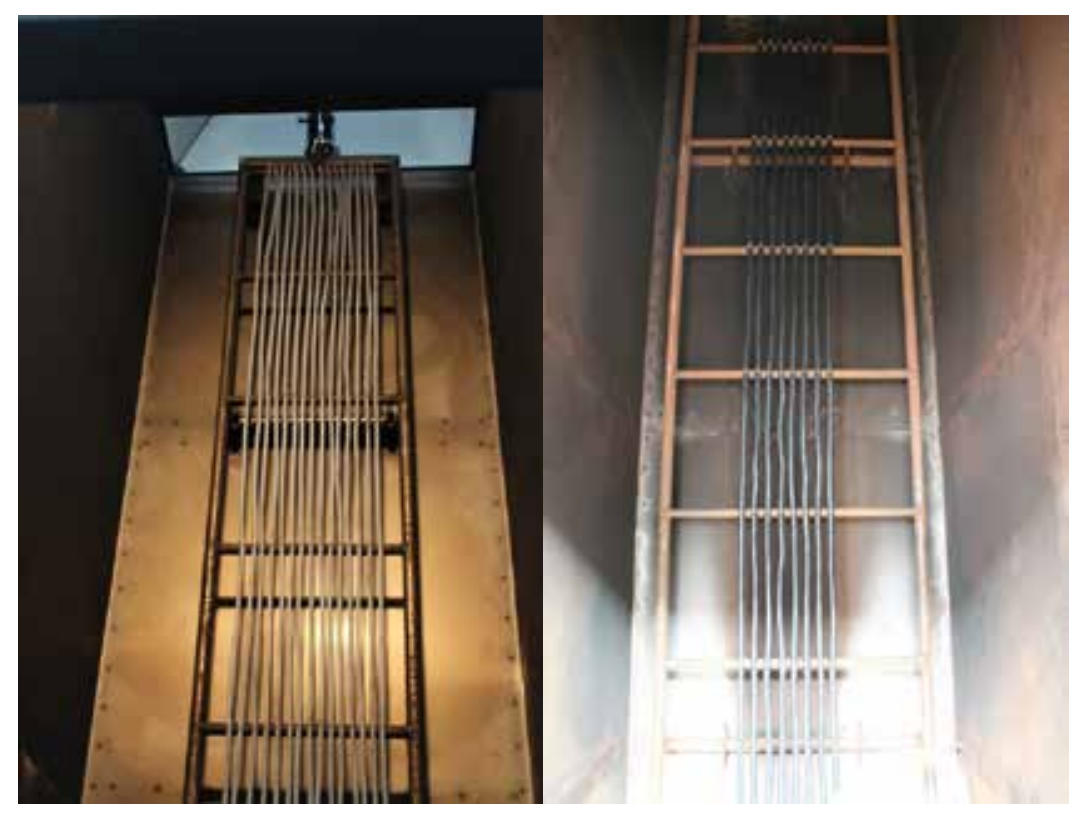

Rycina 12. Komora badawcza przed spalaniem kabli elektrycznych i spaleniu kilku próbek

Figure 12. A test chamber before burning electrical cables and after burning several samples

Source: Materiały ZEPAK.

Source: ZEPAK materials.

\section{Wnioski}

Przy doborze przewodów i kabli elektrycznych w budynku, oprócz aspektów użytkowych w postaci funkcji elektrycznych, należy zwrócić również uwagę na zagrożenia pożarowe, jakie stanowi duże nagromadzenie kabli w wiązkach kablowych. Jak wynika z przeprowadzonej analizy, nie wszystkie kwestie dotyczące wymagań dla kabli są uregulowane przepisami prawa, a w pewnych momentach są nawet uregulowane niewłaściwie.

W związku z powyższym projektanci i rzeczoznawcy ds. zabezpieczeń przeciwpożarowych powinni stosować własną wiedzę techniczną na temat kabli, tym bardziej, że przepisy określają dla tych wyrobów tylko minimalne wymagania. Pomimo funkcjonowania od ponad roku (dwóch przy założeniu okresu przejściowego) wymagań CPR w zakresie określenia reakcji na ogień kabli elektrycznych, przepisy dotyczące zastosowania poszczególnych klas nie zostały opracowane, przez co nie ma jasnego przekazu, jakie wymagania należy stawiać kablom elektrycznym.

Oprócz znajomości obowiązujących wymagań dla kabli elektrycznych i światłowodów, sposobu ich badań oraz zagrożeń, jakie niesie za sobą okablowanie w budynku, przy doborze okablowania potrzebna jest także wiedza techniczna.

Należałoby przyjąć, aby przynajmniej w obszarze dróg ewakuacji, stosowane były kable elektryczne i światłowody o wyższych klasach reakcji na ogień.

\section{Conclusions}

In selecting the electric cables and conduits for a building, in addition to utility aspects such as their electric functions, one should also take into account the fire hazard posed by a large accumulation of cables in cable bundles. The analysis demonstrates that the specification of requirements for cables in the regulations is incomplete and at times even incorrect.

Due to this, designers and fire protection experts should rely on their own technical knowledge, especially because the regulations only specify the minimum requirements for such products. Despite the fact that the CPR requirements for determining the reaction-to-fire performance of electric cables have been in force for more than a year (two years if we take into account the transitional period), the regulations concerning the application of individual classes have not been prepared. As a result, there is no clear specification as to what requirements should apply to electric cables.

In addition to the knowledge of the applicable requirements for electric cables and optical fibre, the testing methods and hazards connected with wiring in buildings, technical knowledge is also essential in selecting cables. An assumption can be made that, at least in the area of escape routes, electric cables and optical fibre with a higher reaction-to-fire performance class should be used. 


\section{Literatura / Literature}

[1] Rozporządzenie Ministra Infrastruktury z dnia 12 kwietnia 2002 r. w sprawie warunków technicznych, jakim powinny odpowiadać budynki i ich usytuowanie (Dz.U. $2002 \mathrm{Nr}$ 75, poz. 690 z późn. zm.).

[2] Rozporządzenia Parlamentu Europejskiego i Rady (UE) NR 305/2011 z dnia 9 marca 2011 r. ustanawiające zharmonizowane warunki wprowadzania do obrotu wyrobów budowlanych i uchylające dyrektywę Rady 89/106/EWG.

[3] Decyzja Komisji z dnia 27 października 2006 r. zmieniająca decyzję Komisji 2000/147/WE wykonującą dyrektywę Rady 89/106/EWG w odniesieniu do klasyfikacji odporności wyrobów budowlanych na działanie ognia (2006/751/WE).

[4] PN-EN 50575:2015-03 Kable i przewody elektroenergetyczne, sterownicze i telekomunikacyjne - Kable i przewody do zastosowań ogólnych w obiektach budowlanych o określonej klasie odporności pożarowej.

[5] PN-EN 13501-6:2014-04 Klasyfikacja ogniowa wyrobów budowlanych i elementów budynków - Część 6: Klasyfikacja na podstawie wyników badań reakcji na ogień kabli elektrycznych.

[6] Rozporządzeniem Ministra Infrastruktury i Budownictwa z dnia 17 listopada 2016 r. w sprawie sposobu deklarowania właściwości użytkowych wyrobów budowlanych oraz sposobu znakowania ich znakiem budowlanym (Dz.U. 2016, poz. 1966 z późn. zm.).

[7] Rozporządzenie Ministra Spraw Wewnętrznych i Administracji z dnia 20 czerwca 2007 r. w sprawie wykazu wyrobów służących zapewnieniu bezpieczeństwa publicznego lub ochronie zdrowia i życia oraz mienia, a także zasad wydawania dopuszczenia tych wyrobów do użytkowania (Dz. U. Nr 143, poz. 1002 z późn. zm.).

[8] Ustawa z dnia 16 kwietnia 2004 r. o wyrobach budowlanych (Dz. U. 2004 Nr 92, poz. 881 z późn. zm.).

[9] Mroczko G., Znaczenie aprobat technicznych dla bezpieczeństwa pożarowego obiektów budowlanych, BiTP Issue 4, 2011.

[10] PN-IEC 60364-5-52:2002 Instalacje elektryczne w obiektach budowlanych - Dobór i montaż wyposażenia elektrycznego - Oprzewodowanie.

[11] Seria PN-EN 60332-1 - Części 1-3: Badania palności kabli przewodów elektrycznych oraz światłowodowych. Sprawdzanie odporności pojedynczego izolowanego przewodu lub kabla na pionowe rozprzestrzenianie się płomienia.

[12] Seria PN-EN 60332-3 - Części 10, 21-25: Badania palności kabli i przewodów elektrycznych oraz światłowodowych. Sprawdzenie odporności na pionowe rozprzestrzenianie się płomienia wzdłuż pionowo zamontowanych wiązek kabli lub przewodów.

[13] PN-HD 60364-4-42:2011 Instalacje elektryczne niskiego napięcia - Części 4-42: Ochrona dla zapewnienia bezpieczeństwa Ochrona przed skutkami oddziaływania cieplnego.
[14] PN-HD 60364-5-51:2011 Instalacje elektryczne w obiektach budowlanych - Części 5-51: Dobór i montaż wyposażenia elektrycznego - Postanowienia ogólne.

[15] PN-EN 61034-2:2010 Pomiar gęstości dymów wydzielanych przez palące się przewody lub kable w określonych warunkach - Część 2: Metoda badania i wymagania.

[16] IEC 60331-1:2009 Tests for electric cables under fire conditions - Circuit integrity - Part 1: Test method for fire with shock at a temperature of at least $830^{\circ} \mathrm{C}$ for cables of rated voltage up to and including $0,6 / 1,0 \mathrm{kV}$ and with an overall diameter exceeding $20 \mathrm{~mm}$.

[17] IEC 60331-21:1999 Tests for electric cables under fire conditions - Circuit integrity - Part 21: Procedures and requirements - Cables of rated voltage up to and including $0,6 / 1,0 \mathrm{kV}$.

[18] Zboina J., Mroczko G., Dostawa energii elektrycznej do urządzeń przeciwpożarowych, BiTP Issue 3, 2013.

[19] PN-EN 50577:2016-02 Kable i przewody elektryczne - Badanie odporności na ogień kabli i przewodów bez ochrony specjalnej (klasyfikacja P).

[20] PN-EN 61537:2007 Prowadzenie przewodów - Systemy korytek i systemy drabinek instalacyjnych.

[21] PN-EN 50200:2016-01 Metoda badania odporności na ogień cienkich przewodów i kabli bez ochrony specjalnej, stosowanych w obwodach zabezpieczających.

[22] PN-EN 50362:2003 Metoda badania palności przewodów i kabli energetycznych i sygnalizacyjnych o większych średnicach, bez ochrony specjalnej, stosowanych w obwodach zabezpieczających.

[23] Rozporządzenie Ministra Infrastruktury z dnia 17 czerwca 2011 r. w sprawie warunków technicznych, jakim powinny odpowiadać obiekty budowlane metra i ich usytuowanie (Dz. U. Nr 144, poz. 859).

[24] Rozporządzenie Ministra Transportu i Gospodarki Morskiej z dnia 30 maja 200 r. w sprawie warunków technicznych, jakim powinny odpowiadać drogowe obiekty inżynierskie i ich usytuowanie (Dz. U. $\mathrm{Nr} 63$, poz. 735 z późn. zm.).

[25] PN-EN 60754-1:2014-11 Badanie gazów wydzielających się podczas spalania materiałów pochodzących z kabli i przewodów - Część 1: Oznaczanie zawartości halogenowodorów.

[26] PN-EN 50399:2011 Wspólne metody badania palności przewodów i kabli - Pomiar wydzielania ciepła i wytwarzania dymu przez kable podczas sprawdzania rozprzestrzeniania się płomienia - Aparatura probiercza, procedury, wyniki.

[27] Bitner, Kable bezhalogenowe, ognioodporne i uniepalnione, 2011.

[28] PN-EN 60754-2:2014-11 Badanie gazów wydzielających się podczas spalania materiałów pobranych z kabli i przewodów - Część 2: Oznaczanie kwasowości (przez pomiar pH) i konduktywności. 
MŁ. BRYG. MGR INŻ. WOJCIECH KLAPSA - absolwent Szkoły Głównej Służby Pożarniczej w Warszawie (2004) i Wojskowej Akademii Technicznej w Warszawie (2006) Wydziału Chemii. Służbę rozpoczął w Jednostce Ratowniczo-Gaśniczej KM w Warszawie, a następnie podjął służbę w Komendzie Wojewódzkiej PSP w Warszawie w wydziale kontrolno-rozpoznawczym. Obecnie pełni służbę w Centrum Naukowo-Badawczym Ochrony Przeciwpożarowej Państwowym Instytucie Badawczym w Józefowie w Zespole Laboratoriów Procesów Spalania i Wybuchowości na stanowisku zastępcy kierownika. Autor lub współautor artykułów o tematyce bezpieczeństwa pożarowego oraz właściwości palnych materiałów budowlanych. W CNBOP-PIB zajmuje się tematyką ekspertyz technicznych budynków, opinii sądowych w zakresie ustalania przyczyn pożarów oraz badaniami w zakresie reakcji na ogień wyrobów budowlanych, a także wyznaczaniem parametrów wybuchowych substancji palnych. Prelegent na konferencjach krajowych i zagranicznych, a także wykładowca podczas ćwiczeń oraz warsztatów i treningów na szkoleniach i kursach.

BRYG. MGR INŻ. DANIEL MAtOZIĘĆ - absolwent Szkoły Głównej Służby Pożarniczej w Warszawie (1990). Obecnie pełni funkcję kierownika w Zespole Laboratoriów Procesów Spalania i Wybuchowości w CNBOP-PIB. Autor licznych artykułów o tematyce bezpieczeństwa pożarowego, właściwości palnych materiałów budowlanych oraz wielu ekspertyz związanych z ustalaniem przyczyn pożarów.

MGR INŻ. ALINA WOLAŃSKA - od 2014 absolwentka Wydziału Inżynierii Materiałowej i Informatyki Przemysłowej na Akademii Górniczo-Hutniczej w Krakowie. Obecnie pracuje jako specjalista w Zespole Laboratoriów Procesów Spalania i Wybuchowości w Centrum Naukowo-Badawczym Ochrony Przeciwpożarowej - PIB w Józefowie. Specjalizuje się w badaniach reakcji na ogień materiałów budowlanych.
JUNIOR BRIG. WOJCIECH KLAPSA, M.SC. ENG. - graduated from the Main School of Fire Service in Warsaw (2004) and the Military University of Technology in Warsaw (2006) in chemistry. He began his service in the Firefighting and Rescue Unit of the municipal fire brigade in Warsaw and then took up work in the Inspection and Identification Department of the Regional Headquarters of the State Fire Service in Warsaw. He is currently employed as the Deputy Head of the Combustion Processes and Explosion Laboratory of CNBOP-BIP in Józefów. Author or co-author of articles on the subject of fire safety and properties of flammable construction materials. His work at $\mathrm{CN}$ BOP-BIP focuses on technological evaluations of buildings, court opinions on the causes of fires and tests of reaction-to-fire performance of construction products, as well as the determination of explosive parameters of flammable substances. He has spoken at national and international conferences and worked as a lecturer teaching classes and conducting training sessions as part of various courses.

BRIG. DANIEL MAŁOZIĘĆ, M.SC. ENG. - graduated from the Main School of Fire Service in Warsaw (1990). He currently works as the Head of the Combustion Processes and Explosion Laboratory of $\mathrm{CN}$ BOP-PIB. He has written numerous articles on fire safety, the properties of flammable building materials and has prepared a number of evaluations determining the causes of fires.

ALINA WOLAŃSKA, M.SC. ENG. - graduated from the Faculty of Metals Engineering and Industrial Computer Science at the AGH University of Science and Technology in Kraków in 2014. She is currently employed as a Specialist at the Combustion Processes and Explosion Laboratory of CNBOP-PIB in Józefów. She specialises in reaction-to-fire performance tests of construction materials. 